\title{
PERSEPSI MASYARAKAT TERHADAP PEMANFAATAN TANAMAN AREN (Arenga pinnata Merr) DI DESA SEKABUK KECAMATAN SADANIANG KABAUPATEN MEMPAWAH
}

\author{
(Community Perception On The Utilization Of Sugar Palm Plants In Village Sekabuk \\ Sadaniang Sub- Distric Mempawah Regency)
}

\author{
Paulus, H. Sofyan Zainal, HA. Oramahi \\ Fakultas Kehutanan Universitas Tanjungpura Jalan Daya Nasional Pontianak 78124 \\ E-mail: pauluslumban55@gmail.com
}

\begin{abstract}
This research is aimed at describing people's perceptions of utilization sugar palm plants in the village of Sekabuk Sadaniang sub-district, as well as analyzing the relationship of each of the factor of age, knowledge, and income with people's perceptions of the utilization of palm plants in the village of Sekabuk Saadaniang sub-district. This research uses direct interview technique method with questionnaire tool, determination of respondents carried out by purposive sampling based on slovin formula amounting to 83 respondents, the criteria of respondents in the research are people who live in the village of Sekabuk, people who know about the use of palm trees, at least 15 years old (already married), physically and mentally healthy. Data analysis consisted of community perceptions of the use of palm trees and the relationship between age, knowledge, and income with community perceptions of the use of palm trees in Sekabuk village. Based on the results of data and calculations of the three variables, forage and knowledge categories there is no relationship with community perceptions, while the income category is related to people's perceptions. The results of the study showed that community perceptions of the utilization of sugar palm plants tended to be positive namely 77 respondents $(92,77 \%)$, neutral 6 respondents $(7,23 \%)$, and negative 0 respondents $(0,00 \%)$. Characteristics of Sekabuk village respondents based on age levels dominated by young and adult levels each of 30 respondents $(36,14 \%)$. Characteristics of respondents based on the level of knowledge dominated by people with a high level of knowledge of 81 respondents (97,60\%), and for the characteristics of respondents based on the level of income dominated with a moderate income level of 65 respondents $(79,52 \%)$.
\end{abstract}

Keywords: Community perception, Utilization Of Palm Sugar Plants

PENDAHULUAN

Hubungan antara masyarakat dalam lingkungannya untuk memenuhi kebutuhan hidup berlangsung seepanjang hayat terutama dengan hutan, dalam upaya memenuhi kebutuhan hidup. Masyarakat sangat bergantung pada sumberdaya alam yang di dalamnya mempunyai fungsi ekologi maupun ekonomi masyarakat dalam memenuhi kebutuhan sehari-harinya.
Sejak tahun 2007, Presiden mencanangkan program nasional penanaman di wilayah indonesia, diperkirakan luas lahan aren sekitar 65.000 hektar, wilayah pengembangan aren tersebar di wilayah Sulawesi Utara, Sulawesi Tenggara, Kalimantan Barat, Kalimantan Timur, Jawa Barat, Jawa Tengah, Jawa Timur, Sumatra Utara, dan Nusa Tenggara Timur (Anonimus 2011). Penelitian tentang persepsi sudah 
banyak dilakukan seperti Paramida C dkk (2019) tentang persepsi masyarakat terhadap dampak konversi lahan hutan menjadi perkebunan kelapa sawit PT. Bumi Pratama Khatulistiwa di Desa Sungai Enau Kecamatan Kuala Mandor B Kabupaten Kubu Raya dan Putra dkk (2018) penelitiannya tentang persepsi dan partisipasi masyarakat dalam kelestarian hutan Rumah Pelangi sebagai kawaasan konservasi.

Kalimantan Barat memiliki sumberdaya alam yang cukup banyak diantaranya adalah flora dan fauna, salah satu adalah Desa Sekabuk yang merupakan kawasan yang mempunyai keanekaragaman hayati yang cukup tinggi yang dapat dimanfaatkan, selain itu Desa Sekabuk yang berada pada lokasi perbukitan menjadikan wilayahnya sangat subur dan ditumbuhi berbagai macam tanaman yang memiliki komoditas ekonomi yang cukup tinggi. Beberapa tanaman yang tumbuh subur di Desa Sekabuk antara lain : aren, kopi, durian, kakao, lada.

Perubahan pola pengelolaan sumberdaya hasil hutan kini memberikan peluang bagi masyarakat sekitar hutan ikut mengelola dan memanfaatkan sumberdaya hutan. Hamzari (2007) mengatakan bahwa masyarakat yang dilibatkan pada pengelolaan hutan diharapkan memberi jaminan kelestarian manfaat produksi, ekologi, serta manfaat sosial bagi masyarakat lokal.

Desa Sekabuk sebagian besar masyarakat menggantungkan hidupnya sebagai petani, sehingga tanaman aren mempunyai potensi yang cukup besar untuk dikembangkan dan dikelola secara lestari dan berkelanjutan yang dapat berdampak baik dari segi sosial maupun ekonomi masyarakat sekitar, dan pada dasarnya masyarakat Desa Sekabuk memanfaatkan dan mengelola tanaman aren secara tradisional dan turun-temurun dalam memenuhi kebutuhan sehari-hari. Gultom (2009) mengatakan bahwa aren merupakan salah satu tanaman perkebunan jenis palma yang memiliki potensi nilai ekologi dan ekonomi yang tinggi.

Tujuan dari penelitian ini adalah untuk mengetahui persepsi masyarakat terhadap pemanfaatan tanaman aren di Desa Sekabuk Kecamatan Sadaniang Kabupaten Mempawah, mengetahui hubungan dari masing-masing faktor umur, pengetahuan, dan pendapatan dengan persepsi masyarakat terhadap pemanfaatan tanaman aren di Desa Sekabuk.

\section{METODE PENELITIAN}

Penelitian ini dilaksanakan di Desa Sekabuk selama \pm 4 minggu dari bulan Febuari sampai Maret 2019 efektif di lapangan. Penelitian dilakukan dengan metode survey teknik wawancara langsung dengan alat bantu kuesioner, alat yang digunakan dalam penelitian ini terdiri dari peta lokasi penelitian, kamera, kalkulator dan kuesioner. Objek Penelitian adalah masyarakat Desa Sekabuk terhadap pemanfaatan tanaman aren. Metode pengambilan sampel responden pada penelitian ini adalah dengan teknik purvosive sampling yaitu teknik pengambilan 
sampel berdasarkan kesengajaan dan pertimbangan tertentu (Sugiyono 2010).

Untuk menentukan besarnya sampel dihitung dengan rumus Slovin (Noor, 2011) sebagai berikut:

$$
n=\frac{N}{1+N(e)^{2}}
$$

Keterangan :

$\mathrm{n} \quad=$ Jumlah sampel

$\mathrm{N}=$ Jumlah populasi

e = batas toleransi kesalahan (persen kesalahan)

Dengan menetapkan rumus diatas, maka jumlah sampel yang diperoleh dengan taraf signifikan $10 \%$ yaitu :

$$
\begin{gathered}
\mathrm{n}=\frac{500}{1+500(0,01)^{2}}=\frac{500}{6}=83,333 \\
=83 \mathrm{KK}
\end{gathered}
$$

Tabel 1. Daftar Jumlah Populasi Sebagai Sampel Dalam Penelitian ( A List Of The Population A Sample In The Study).

\begin{tabular}{cccc}
\hline No & Nama Dusun & Jumlah KK & Sampel KK \\
\hline 1. & Sekabuk & 97 & 16 \\
2. & Titidahan & 137 & 23 \\
3. & Gelombang & 123 & 20 \\
4 & Pak Nungkat & 143 & 24 \\
\hline & Jumlah & 500 & 83 \\
\hline
\end{tabular}

Data yang dikumpulkan antara lain data primer tentang persepsi masyarakat terhadap pemanfaatan tanaman aren di Desa Sekabuk Kecamatan Sadanianag, yang akan dihubungkan menurut tingkat umur, pengetahuan dan pendapatan, (2) data sekunder yaitu data penunjang yang berhubungan dengan keadaan lokasi penelitian, diperoleh dari intansi terkait yang menunjang hasil penelitian. Data tersebut di tabulasikan dan kemudian dianalisis dengan menggunakan Chi Square.
Kriteria masyarakaat yang dijadikan responden secara pureposive sampling adalah: (1).Sebagai kepala keluarga dan berdomisili di Desa Sekabuk, (2). Lama menetap minimal 5 tahun, (3). Umur minimal 15 tahun (sudah berkeluarga), (4). Sehat jasmani dan rohani, (5). Masyarakat yang mengetahui tentang pemanfaatan tanaman aren.

Berdasarkan rumus Slovin tersebut didapat total 83 responden. Total 83 responden tersebut untuk lebih jelasnya dapat dilihat pada Tabel 1.
HASIL DAN PEMBAHASAN

Berdasarkan hasil penelitian, diperoleh kategori frekuensi persepsi responden terhadap pemanfaatan tanaman aren yakni (1) persepsi positif sebanyak 77 responden $(92,77 \%)$, (2) persepsi netral sebanyak 6 responden (7,23\%), dan (3) persepsi negatif sebanyak 0 responden (70,00). Frekuensi persepsi responden terhadap pemanfaatan tanaman aren seperti yang disajikan pada Tabel 3 . 
Tabel 2. Persepsi masyarakat terhadap pemanfaatan tanaman aren di Desa Sekabuk Kecamatan Sadaniang Kabupaten Mempawah (Frequency of respondents based on perceptions of utilization sugar palm plants In Village Sekabuk, Sadaniang Sub-Districk, Mempawah Regency)

\begin{tabular}{cccc}
\hline No & Kategori Persepsi & Frekuensi & Persentase (\%) \\
\hline 1. & Positif & 77 & 92,77 \\
2. & Netral & 6 & 7,23 \\
3. & Negatif & 0 & 0,00 \\
\hline & Jumlah & 83 & 100 \\
\hline
\end{tabular}

Berdasarkan hasil penelitian yang telah dilakukan, menunjukan bahwa persepsi masyarakat Desa Sekabuk Kecamatan Sadaniang terhadap pemanfaatan tanaman aren cenderung tinggi yaitu sebanyak $77 \quad(92,77 \%)$ responden memiliki persepsi tinggi. Menurut Wibowo (2013) bahwa kesadaran dan peran partisipasi aktif masyarakat juga penting dalam kelestarian hutan, karena masyarakat sekitar hutan berhubungan langsung dengan keberadaan hutannya, dan kelestarian hutan tidak saja menjadi tanggung jawab pemerintah.

Responden yang memiliki persepsi sedang ialah responden yang mengetahui keberadaan tanaman aren namun tidak sepenuhnya memahami dan mengetahui tujuan dan fungsi dari pengelolaan dan pemanfaatan tanaman aren tersebut.

Hubungan antara tingkat umur dengan persepsi masyarakat terhadap pemanfaatan tanaman aren Di Desa Sekabuk Kecamatan Sadaniang dapat dilihat pada Tabel 3.

Tabel 3. Hubungan Persepsi Masyarakat dengan Tingkat Umur (The relationship between community perception and age level)

\begin{tabular}{|c|c|c|c|c|c|c|c|}
\hline \multirow{2}{*}{ Kategori Persepsi } & \multicolumn{3}{|c|}{ Kategori } & \multicolumn{3}{|l|}{ Umur } & \multirow{2}{*}{ Tota } \\
\hline & M & $\%$ & $\mathrm{D}$ & $\%$ & $\mathrm{~T}$ & $\%$ & \\
\hline Positif & 26 & 86,67 & 28 & 93,33 & 23 & 100 & 77 \\
\hline Netral & 4 & 13,33 & 2 & 6,67 & 0 & 0 & 6 \\
\hline Negatif & 0 & 0 & 0 & 0 & 0 & 0 & 0 \\
\hline Total & 30 & 100 & 30 & 100 & 23 & 100 & 83 \\
\hline
\end{tabular}

Berdasarkan hasil penelitian diketahui bahwa hubungan tingkat umur pada Tabel 3 dapat diinterprestasikan sebagai berikut : (1). Dari 30 responden pada kategori usia muda, $26(86,67 \%)$ responden memberikan persepsi tinggi, $4(13,33 \%)$ responden memberikan persepsi sedang dan $0 \quad(0,00 \%)$ responden memberikan persepsi rendah,
(2). Dari 30 responden pada kategori usia dewasa, $28(93,33 \%)$ responden memberikan persepsi tinggi, 2 $(6,67 \%)$ responden memberikan persepsi sedang dan $0 \quad(0,00 \%)$ responden memberikan persepsi rendah. (3). Sebanyak 23 responden pada kategori usia tua, 23 (100\%) responden 
keseluruhannya memberikan persepsi tinggi.

Hasil uji statistik antara persepsi masyarakat terhadap pemanfaatan tanaman aren di Desa Sekabuk dengan tingkat umur diperoleh nilai koefisien $\mathrm{X}^{2}$ hitung $=3,47$ sedangkan $\mathrm{X}^{2}$ tabel $=9,448 \quad\left(X^{2}\right.$ hitung $<X^{2}$ tabel $)$ dengan demikian dapat disimpulkan bahwa tidak terdapat hubungan antara tingkat umur terhadap persepsi masyarakat terhadap pemanfaatan tanaman aren Di Desa Sekabu, maka hipotesis asosiatif yang digunakan adalah terima $\mathrm{H}_{0}$ tolak $\mathrm{H}_{1}$.

Masyarakat dengan tungkat usia muda dan dewasa memberikan persepsi yang sedang terhadap pemanfaatan tanaman aren di Desa Sekabuk

Tabel 4. Hubungan Persepsi Masyarakat dengan Tingkat Pengetahuan (The relationship Of community with the level of knowledge)

\begin{tabular}{|c|c|c|c|c|c|c|c|}
\hline \multirow{2}{*}{ Kategori Persepsi } & \multicolumn{3}{|c|}{ Kategori } & \multicolumn{3}{|c|}{ Pengetahuan } & \multirow{2}{*}{ Tota } \\
\hline & $\mathrm{T}$ & $\%$ & $\mathrm{~S}$ & $\%$ & $\mathrm{R}$ & $\%$ & \\
\hline Positif & 76 & 93,83 & 1 & 50 & 0 & 0 & 77 \\
\hline Netral & 5 & 6,17 & 1 & 50 & 0 & 0 & 6 \\
\hline Negatif & 0 & 0 & 0 & 0 & 0 & 0 & 0 \\
\hline Total & 81 & 100 & 2 & 100 & & 100 & 83 \\
\hline
\end{tabular}

Berdasarkan hasil penelitian bahwa hubungan tingkat pengetahuan pada tabel 4 dapat diinterprestasikan sebagai berikut : (1). Dari 81 responden pada kategori pengetahuan tinggi, 76 $(93,83 \%)$ responden memberikan persepsi tinggi, $5(6,17 \%)$ responden memberikan persepsi sedang dan 0 $(0,00 \%)$ responden memberikan persepsi rendah, (2). Dari 2 responden pada kategori pengetahuan sedang, 1 (50\%) responden memberikan persepsi tinggi, $1(50 \%)$ responden memberikan
Kecamatan Sadaniang ini menyatakan bahwa usia tidak membatasi seseorang untuk mengetahui dan menerima manfaat dari segala sesuatu bagi kehidupan setiap individu. Hal ini sejalan dengan pendapat Hersojo (1996) dalam Peres (2012) bahwa faktor umur tidak memiliki peran penting pada diri seseorang dalam menentukan apakah seseorang itu mempunyai pengetahuan banyak atau tidak dan tidak menentukan kebebasan seseorang dalam bertindak.

Hubungan antara tingkat pengetahuan dengan persepsi masyarakat terhadap pemanfaatan tanaman aren Di Desa Sekabuk Kecamatan Sadaniang dapat dilihat pada Tabel 4. 
tanaman aren, maka hipotesis asosiatif yang digunakan adalah terima $\mathrm{H}_{0}$ tolak $\mathrm{H}_{\mathrm{i} .}$ Ini sejalan dengan persepsi Sueca et al (2001) bahwa tingkat pengetahuan masyarakat dapat berpengaruh terhadap persepsi dan perilakunya, artinya semakin tinggi tingkat pengetahuan seseorang maka diharapkan persepsi dan perilakunya semakin bertambah baik.

Responden yang pengetahuan sedang juga memiliki persepsi yang tinggi terhadap pemanfaatan tanaman aren di Desa Sekabuk ini menyatakan pengetahuan seseorang berpengaruh terhadap pandangan seseorang jika pengetahuan mereka rendah maupun sedang bukan berarti pemahaman

Tabel 5. Hubungan Persepsi Masyarakat dengan Tingkat Pendapaatan (The relationship between community Perception And Income Level)

\begin{tabular}{|c|c|c|c|c|c|c|c|}
\hline \multirow{2}{*}{ Kategori Persepsi } & \multicolumn{3}{|c|}{ Kategori } & \multicolumn{3}{|c|}{ Pendapatan } & \multirow{2}{*}{ Tota } \\
\hline & $\mathrm{T}$ & $\%$ & $\mathrm{~S}$ & $\%$ & $\mathrm{R}$ & $\%$ & \\
\hline Positif & 6 & 75 & 64 & 98,46 & 7 & 70 & 77 \\
\hline Netral & 2 & 25 & 1 & 1,54 & 3 & 30 & 6 \\
\hline Negatif & 0 & 0 & 0 & 0 & 0 & 0 & 0 \\
\hline Total & 8 & 100 & 65 & 100 & 10 & 100 & 83 \\
\hline
\end{tabular}

Berdasarkan hasil penelitian hubungan tingkat pendapatan pada tabel 5 dapat diinterprestasikan sebagai berikut : (1). Dari 8 responden pada kategori pendapatan tinggi, 6 (75\%) responden memberikan persepsi tinggi, 2 (25\%) responden memberikan persepsi sedang dan $0(0,00 \%)$ responden memberikan persepsi rendah, (2). Dari 65 responden pada kategori pendapatan sedang, 64 $(98,46 \%)$ responden memberikan persepsi tinggi, $1(1,54 \%)$ responden memberikan persepsi sedang dan $0(0,00 \%)$ responden memberikan persepsi rendah. (3). Dari 10 mereka kurang melainkan masyarakat menilai sendiri berdasarkan apa yang mereka lihat, berdasarkan pengetahuan dan pengalaman yang mereka miliki. Menurut Rian (2004) dalam Milunardi dkk (2014), bahwa pengetahuan adalah suatu gejala yang ditemui dan diperoleh melalui pengamatan serta pengetahuan seseorang yang dapat mempengaruhi pola pikir, tingkat kesadaran, sikap atau prilaku seseorang terhadap kegiatan yang dilakukan.

Hubungan antara tingkat pendapatan dengan persepsi masyarakat terhadap pemanfaatan tanaman aren Di Desa Sekabuk Kecamatan Sadaniang dapat dilihat pada tabel 5 . 
dengan demikian dapat disumpulkan bahwa terdapat hubungan antara pendapatan dengan persepsi masyarakat, maka hipotesis asosiatif yang digunakan adalah terima $\mathrm{H}_{1}$ tolak $\mathrm{H}_{0}$.

Keberadaan tanaman aren dapat mempengaruhi tinggi rendahnya pendapataan masyarakat ini dikarenakan pendapatan masyarakat di Desa Sekabuk Kecamatan Sadaniang sebagian besar ratarata berkerja sehari-hari sebagai petani maupun memanfaatkaan hasil dari alam, dan masyarakat juga dapat secara langsung maupun tidak langsung merasakan dampak baik bagi alam, lingkungan, sosial dan ekonomi yang dirasakan oleh masyarakat sehari-hari dan masa akan datang. Sejalan dengan persepsi Fauzi (2012) bahwa hubungan manusia dengan alam pada dasarnya bersifat kebudayaan dalam arti nilai-nilai manusia mengenai pencakupan kebutuhan atau bersifat sosial mencakup pengaturan-pengaturan kelembagaan khusus yang melibatkan pengaruh fisik lingkungan dan kelestarian hutan yang hanya dapat diwujudkan jika masih menjunjung tinggi nilai-nilai kebudayaan dan terdapat hubungan yang harmonis antara manusia dengan hutan.

\section{Kesimpulan}

Berdasarkan hasil penelitian tentang persepsi masyarakat terhadap pemanfaatan tanaman aren di Desa Sekabuk Kecamatan Sadaniang Kabupaten Mempawah dapat disimpulkan sebagai berikut:

1. Persepsi masyarakat Desa Sekabuk Kecamatan Sadaniang terhadap pemanfaatan tanaman aren cenderung positif $(92,77 \%)$.
2. Variabel tingkat umur, dan tingkat pengetahuan tidak mempengaruhi persepsi masyarakat terhadap pemanfaatan tanaman aren di Desa Sekabuk Kecamatan Sadaniang Kabupaten Mempawah, Sedangkan variabel tingkat pendapatan mempengaruhi persepsi masyarakat terhadap pemanfaatan tanaman aren di Desa Sekabuk Kecamatan Sadaniang Kabupaten Mempawah.

a. Hasil analisis chi kuadrat antara persepsi masyarakat terhadap pemanfaatan tanaman aren di Desa Sekabuk dengan tingkat umur diperoleh nilai koefisien $\mathrm{X}^{2}$ hitung $=3,47$ sedangkan $X^{2}$ tabel $=9,448$ sehingga dapat disimpulkan bahwa $X^{2}$ hitung < $X^{2}$ tabel dengan demikian disimpulkan, bahwa tidak terdapat hubungan antara persepsi masyarakat terhadap pemanfaatan tanaman aren dengan tingkat umur masyarakat.

b. Hasil analisis chi kuadrat antara persepsi masyarakat terhadap pemanfaatan tanaman aren di Desa Sekabuk dengan tingkat pengetahuan masyarakat diperoleh nilai koefisien $\mathrm{X}^{2}$ hitung $=5,58$ sedangkan $\quad \mathrm{X}^{2}$ tabel $=9,448$ sehingga dapat disimpulkan bahwa $X^{2}$ hitung < $X^{2}$ tabel dengan demikian dapat disimpulkan, bahwa tidak terdapat hubungan antara persepsi masyarakat terhadap pemanfaatan tanaman aren di Desa Sekabuk dengan tingkat pengetahuan masyarakat. 
c. Hasil analisis chi kuadrat antara persepsi masyarakat terhadap pemanfaatan tanaman aren di Desa Sekabuk dengan tingkat pendapatan masyarakat diperoleh nilai koefisien $\mathrm{X}^{2}$ hitung $=14,63$ sedangkan $\mathrm{X}^{2}$ tabel $=9,448$ sehingga dapat disimpulkan bahwa $\mathrm{X}^{2}$ hitung $>\mathrm{X}^{2}$ tabel dengan demikian dapat disimpulkan, bahwa terdapat hubungan antara pendapatan dengan persepsi masyarakat terhadap pemanfaatan tanaman aren dengan tingkat keeratan yang cukup signifikan dimana selisih $\mathrm{C}$ max dikurang $\mathrm{C}$ sama dengan 0,74070 lebih kecil dari 1.

\section{Saran}

Perlu ditingkatkan kesadaran dan pengetahuan masyarakat Desa Sekabuk terkait tentang aren dan bagaimana mengelola potensi aren yang ada di wilayah mereka. Untuk itu diperlukan dukungan dari berbagai pihak baik itu dari pemerintah pusat, pemerintah daerah, serta pihak intansi terkait harus lebih meningkatkan lagi komunikasi dengan masyarakat dan terus melakukan penyuluhan maupun pelatihan dalam hal pengerjaan aren yang terpadu dan berkelanjutan kepada masyarakat agar masyarakat sekitar sadar akan potensi yang ada di wilayah mereka.

\section{DAFTAR PUSTAKA}

Anonimous, 2010, Manfaat Pohon Aren, http://katakimutz.student.umm.ac.id/9/k atak imutz, diakses tanggal 25 April 2015.
Fauzi. H . 2012. Pembangunan Hutan

Berbasis Kehutanan Sosial.

Karya Putra Semarang.

Gultom. 2009. Jutaan Dolar Harta Karun Tersimpan dalam Pohon Aren atau Enau Alias Bagot [Internet]. Diakses pada : 2017 Mei 19. Tersedia pada : http://arenindonesia.wordpress.com/ artikel-aren/hltgultom.

Hamzari. 2007. "Identifikasi Tanaman Obat-obatan yang Dimanfaatkan oleh

Mastarakat Sekitar Hutan Tabotabo". Hutan Dan Masyarakat 1(2):111234.

Milunardi, Fahrizal dan Iskandar. 2014. Partispasi Masyarakat Sekitar Hutan Dalam Melestarikan Hutan Adat Sebagai Daerah Penyangga Sumber Air di Desa Menyabo Kecamatan Tayan Hulu Kabupaten Sanggau. Jurnal Hutan Lestari. Vol 02. No 02.

Noor J, 2011. Metodologi Penelitian. Kencana Prenada Media Group. Jakarta

Paramida C, Emi Roslinda, dan Evy Wadenar. Persepsi Masyarakat Terhadap Danpak Konversi Lahan Hutan Menjadi Perkebunan Kelapa Sawit PT. Bumi Pratama Khatulistiwa di Desa Enau Kecamatan Kuala Mandor B Kabupaten Kubu Raya. Fakultas KehutananUniversitas Tanjungpura Pontianak.Jurnal Hutan Lestari. Vol. 7 (4) : 1524-1538.

Peres Simon. 2012. Persepsi Masyarakat Menterado Terhadap Kawasan Cagar Alam Lho Fat Fun Fie di Kecamatan Menterado Kabupaten Bengkayang. [Skripsi]. Fakultas 
JURNAL HUTAN LESTARI (2020)

Vol. 8 (1) : 41 - 49

Kehutanan Universitas Tanjungpura

Pontianak>

Putra SW, Sofyan Zainal, dan Ahmad

Yani. 2018. Persepsi Dan

Partisipasi Masyarakat Dalam

Pelestarian Hutan Rumah Pelangi

Sebadai Kawasan Konservasi.

Fakultas Kehutanan Universitas

Tanjungpura Pontianak. Jurnal

Tengkawang Vol. 8 (1) : 26-37.

Sueca NP., Ida B.G.P., Ketut Muliawan S.

Wayan N, Dw. Nym. Wastika.

2001.Faktor-Faktor Derteminan

Pengetahuan Dan Persepsi

Masyarakat Tentang Bangunan

Berlanggam Bali. Dimensi Teknik Arsitektur, Vol 29, No2

Sugiyono. 2011. Metode Penelitian Kuantitatif, Kualitatif Dan $R \& D$. Bandung: Alfabeta.

Wibowo, 2009. Motivasi Dan Partisipasi Masyarakat Desa Buluh Cina Dalam Upaya Melestarikan Hutan Adat Buluh Cina Kec Siak Hulu Kab Kampar Provinsi Riau. Jurnal Lingkungan Hidup. Vol.1. 